\title{
CLINICAL BENEFITS AFTER THE IMPLEMENTATION OF A MULTIMODAL PERIOPERATIVE PROTOCOL IN ELDERLY PATIENTS
}

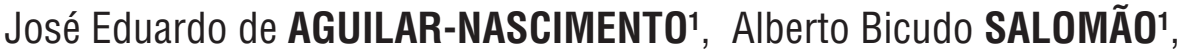 \\ Cervantes CAPOROSSI ${ }^{1}$ and Breno Nadaf DINIZ²
}

\begin{abstract}
Context - Multimodal protocol of perioperative care may enhance recovery after surgery. Based on evidence these new routines of perioperative care changed conventional prescriptions in surgery. Objective - To evaluate the results of a multimodal protocol (ACERTO protocol) in elderly patients. Methods - Non-randomized historical cohort study was performed at the surgical ward of a tertiary university hospital. One hundred seventeen patients aged 60 and older were submitted to elective abdominal operations under either conventional ( $n=42$; conventional group, January 2004-June 2005) or a fast-track perioperative protocol named ACERTO ( $\mathrm{n}$ =75; ACERTO group, July 2005-December 2007). Main endpoints were preoperative fasting time, postoperative day of re-feeding, volume of intravenous fluids, length of hospital stay and morbidity. Results - The implantation of the ACERTO protocol was followed by a decrease in both preoperative fasting (15 [8-20] vs 4 [2-20] hours, $P<0.001)$ and postoperative day of refeeding (1st [1st-10th] vs 0 [0-5th] PO day; $P<0.01)$, and intravenous fluids $(10.7$ [2.5-57.5] vs 2.5 [0.5-82] $\mathrm{L}, P<0.001)$. The changing of protocols reduced the mean length of hospital stay by 4 days $(6[1-43]$ vs 2[1-97] days; $P=0.002)$ and surgical site infection rate by $85.7 \%(19 \% ; 8 / 42$ vs $2.7 \% ; 2 / 75, P<0.001$; relative risk $=1.20 ; 95 \%$ confidence interval $=1.03-1.39)$. Per-protocol analysis showed that hospital stay in major operations diminished only in patients who completed the protocol $(P<0.01)$. Conclusion - The implementation of multidisciplinary routines of the ACERTO protocol diminished both hospitalization and surgical site infection in elderly patients submitted to abdominal operations.
\end{abstract}

HEADINGS - Perioperative care. Postoperative care. Length of stay. Aged. Protocols.

\section{INTRODUCTION}

Consistent evidence-based studies have been showing that various routines in perioperative care are useless and in some cases harmful ${ }^{(24)}$. Most of the current management of surgical patients is grounded in empirism ${ }^{(12)}$. Overnight preoperative fasting, postoperative re-feeding after ileus resolution, routine use of nasogastric tube and abdominal drains, and preoperative mechanical bowel cleansing for colorectal operations are some of the conventional prescriptions followed by surgeons in many countries ${ }^{(12,18,24)}$. In addition, perioperative nutritional support is frequently neglected ${ }^{(31)}$. The results reported by both the Enhanced Recovery After Surgery (ERAS) and ACERTO ("Aceleração da Recuperação Total") protocols, in Europe and in Brazil, have shown that the adoption of multimodal strategies of perioperative care are associated with both faster postoperative hospitalization and decrease of infectious morbidity ${ }^{(2,4,12,13,18,24)}$.
However, most of the studies reporting the advantages of multimodal protocols have focused on either a specific type of operation such as colorectal resections or in cases of general surgery. We speculate that these multimodal strategies may benefit elderly patients. Life expectancy has been increasing in many countries and it is augmenting the proportion of elderly patients undergoing operations ${ }^{(9,17)}$. Elderly patients are most prone to postoperative complications, are usually candidates to major operations, and are most susceptible to homeostasis variations ${ }^{(17)}$. In addition, they have frequently various co-morbidities such as diabetes, arterial hypertension, chronic pulmonary diseases, and cardiovascular disorders ${ }^{(6,17)}$.

In 2005, the Department of Surgery of the Julio Muller University Hospital, Universidade Federal do Mato Grosso, Cuiabá, MT, Brazil, initiated the ACERTO project which is a multidisciplinary project with various new routines of perioperative care $^{(2,4)}$. The project was named ACERTO because it is a Portuguese word

Department of Surgery, Universidade Federal de Mato Grosso (UFMT), ${ }^{2}$ Medical School, UFMT Cuiabá, MT, Brazi

Correspondence: Prof. José Eduardo de Aguilar-Nascimento - Rua Estevão de Mendonça, 81 - apt. 801 - 78043-300 - Cuiabá, MT, Brazil. E-mail: aguilar@terra.com.br 
meaning "hit the target", "get it right" or "rightness" and at the same time a Portuguese acronym for ERAS.

This study aimed at comparing the clinical outcome before and after the implementation of this multimodal perioperative protocol in a population of elderly subjects who underwent abdominal operations.

\section{METHODS}

We prospectively studied all patients above 60 years-old admitted at the Department of Surgery of the Julio Muller University Hospital, and candidate to elective abdominal operations from January 2004 to December 2007. The study design was approved by the Ethical Research Committee of the hospital.

We decided to investigate in the prospective database of the Department of Surgery the clinical outcome of the elderly patients in two distinct periods: before (January 2004 to June 2005), and after the implementation of the ACERTO protocol (July 2005 to December 2007). The new protocol was implemented in July 2005 as previously described ${ }^{(4)}$. After the commencement of ACERTO protocol, the staff was not obligated to follow the various new routines. Instead, adherence to the new protocol was let be in a free-willing basis. Audits were conducted every 3 months and comparisons between before and after the initiation of the ACERTO protocol were showed to all staff. Figure 1 shows the two protocols followed by the Department of Surgery in the first and second period of the study.

\begin{tabular}{|c|c|}
\hline Conventional care & ACERTO project care \\
\hline Preoperative counseling at surgeon discretion & Oral preoperative counseling \\
\hline Preoperative fasting of $8 \mathrm{~h}$ & $\begin{array}{l}\text { Preoperative fasting of } 2 \mathrm{~h} \text {. Six and } 2 \mathrm{~h} \\
\text { before operation the patient drank } 400 \text { and } \\
200 \mathrm{~mL} \text { of a beverage containing } 12.5 \% \text { of } \\
\text { maltodextrine }\end{array}$ \\
\hline Postoperative feeding after ileus resolution & $\begin{array}{l}\text { Early oral or enteral postoperative feeding } \\
(6-24 \mathrm{~h})\end{array}$ \\
\hline $\begin{array}{l}\text { Preoperative nutritional support if } \\
\text { malnourished and candidate to major } \\
\text { operation }\end{array}$ & $\begin{array}{l}\text { Preoperative nutritional support if } \\
\text { malnourished and candidate to major } \\
\text { operation }\end{array}$ \\
\hline $\begin{array}{l}\text { Mechanical bowel preparation for colorectal } \\
\text { operations }\end{array}$ & No mechanical bowel preparation \\
\hline $\begin{array}{l}\text { Intravenous fluids at a rate of } 30-50 \mathrm{~mL} / \mathrm{kg} \text { / } \\
\text { day usually until the } 3-4 \text { th PO day }\end{array}$ & $\begin{array}{l}\text { Avoid excessive intravenous fluid (no more } \\
\text { than } 30 \mathrm{~mL} / \mathrm{kg} / \text { day). No IV fluids for minor } \\
\text { operations postoperatively. Discontinuation } \\
\text { of IV fluids, if possible, on the } 1 \mathrm{st} \text { PO day }\end{array}$ \\
\hline $\begin{array}{l}\text { Abdominal drainage and nasogastric tube at } \\
\text { surgeon discretion }\end{array}$ & Avoid drains and nasogastric tubes \\
\hline Mobilization on the 1 st PO day & $\begin{array}{l}\text { Early mobilization (if possible on the same } \\
\text { day of the operation) }\end{array}$ \\
\hline
\end{tabular}

FIGURE 1. Conventional and the ACERTO routines of perioperative care

The surgical procedures were divided as major and minor operations. Major operations included open laparotomies lasting for more than $3 \mathrm{~h}$, and procedures with at least one anastomosis performed at either the gastrointestinal tract or billiary tree. As minor operations were included video or open cholecistectomies, hernioraphies, videolaparoscopies for diagnosis and biopsy, and laparotomies lasting less than $3 \mathrm{~h}$. Nutritional status was assessed by subjective global assessment ${ }^{(11)}$. Patients were categorized as malnourished or non-malnourished.

Variables collected in both study periods were preoperative fasting time, indication and utilization of preoperative nutritional support, volume of perioperative intravenous fluids, and the day of postoperative re-feeding. The main endpoints were postoperative morbidity, mortality, and postoperative length of hospital stay (LOS). As adherence to ACERTO protocol was not compulsory, the intention to treat analysis was complemented with per-protocol analysis (including patients who completed or did not complete the ACERTO protocol). Chi-square test or Fisher's test were used to compare categorical data. The Kruskall-Wallis test (complemented with Bonferroni test as needed) or MannWhitney test was used to compare continuous data. A 5\% $(P<0.05)$ level was established for significance.

\section{RESULTS}

A total of 117 patients $($ male $=75 ; 64.1 \%$ and female $=42$; $35.9 \%)$ with a median age of $67(60-85)$ year old out of all 514 patients operated on during the period entered the study. Fortytwo $(35.9 \%)$ patients were operated on before (conventional group) and $75(64.1 \%)$ after the implementation of the new ACERTO protocol (ACERTO group). Nineteen (45.2\%) patients of the ACERTO group and 35 (45.6\%) patients of the conventional group underwent major procedures $(P>0.05)$. Table 1 shows the distribution of the operations performed in the two periods. Demographics of patients included in the two periods can be seen in Table 2. In the second period of the study, the ACERTO protocol was fulfilled in 40 patients.

TABLE 1. Distribution of the operations before and after the ACERTO protocol

\begin{tabular}{lcc}
\hline Operation & Before ACERTO & After ACERTO \\
\hline Pancreatectomy & 2 & 3 \\
Esophagectomy & 1 & 4 \\
Total gastrectomy & 1 & 2 \\
Subtotal gastrectomy & 2 & 7 \\
Bilio-digestive anastomosis & 2 & 4 \\
Laparotomy $^{\text {Colorrectal }}{ }^{\text {a }}$ & 6 & 6 \\
Herniorraphy $^{\text {Cholecistectomy }}{ }^{\mathrm{b}}$ & 11 & 9 \\
Total $^{2}$ & 8 & 21 \\
${ }^{2}$ Segmental colectomy, abdomino-perineal resection of the rectum, colorectal pull-through, and colostomy closure;
\end{tabular}

Five operations before ACERTO and 10 after ACERTO were laparoscopic

TABLE 2. Demographics of patients before and after the ACERTO protocol

\begin{tabular}{lccc}
\hline \multirow{2}{*}{ Variable } & \multicolumn{3}{c}{ Period of the study } \\
\cline { 2 - 4 } & $\begin{array}{c}\text { Before ACERTO } \\
(\mathrm{n}=42)\end{array}$ & $\begin{array}{c}\text { After ACERTO } \\
(\mathrm{n}=75)\end{array}$ & $\boldsymbol{P}$ \\
\hline Gender (M/F) & $27 / 15$ & $48 / 27$ & 1.00 \\
Age (years)* & $67.5(60-85)$ & $67(60-84)$ & 0.29 \\
Operative time (minutes)* & $180(55-540)$ & $140(30-570)$ & 0.22 \\
Malnutrition (n; \%) & $23(54.7)$ & $51(68)$ & 0.15 \\
Malignancies (n; \%) & $17(40.5)$ & $24(32)$ & 0.36 \\
Major operations (n; \%) & $19(42.2)$ & $35(45.6)$ & 1.00 \\
ASA score (I/II/III) & $10 / 29 / 3$ & $21 / 45 / 9$ & 0.56 \\
\hline
\end{tabular}

*Median and range;

ASA $=$ American Society of Anesthesiologists 


\section{Perioperative nutritional support}

Malnutrition was found in $74(63.2 \%)$ cases with similar distribution between groups $(P=0.15)$. All malnourished patients who were candidates for major operations received either oral supplements or specialized nutritional support preoperatively for 7-14 days.

\section{Preoperative fasting}

Patients underwent operations by the conventional protocol remained a median of 15 [8-20] h fasting preoperatively, and thus 2-fold longer than the prescribed $8 \mathrm{~h}$. In the second period there was a significant fall $(P<0.001)$ in preoperative fasting time (4 [2-20] h).

\section{Postoperative feeding}

Patients were fed 1 day earlier after the implementation of the ACERTO protocol. Median time for postoperative feeding was the 1st PO day (1st [0-10th] PO day) in conventional group and the same day of operation ( 0 [0-5th] PO day) in the ACERTO $\operatorname{protocol}(P<0.001)$. Reintroduction of diet was earlier in both minor (0 [0-1st] vs 1 st $[0-2$ nd] PO day; $P<0.001)$ and major operations (1st [0-5th] vs 2nd [1st-10th] PO day; $P<0.001)$.

\section{Perioperative intravenous fluids}

Preoperative intravenous fluids were similarly prescribed in both periods (data not shown). However, the amount of crystalloid intravenous fluids prescribed postoperatively significantly fell after the ACERTO protocol. The median total volume of fluids received per patient was approximately 4-fold greater $(P<0.001)$ before $(10.7[2.5-57.5] \mathrm{L})$ than after the ACERTO protocol $(2.5[0.5-82] \mathrm{L})$. This pattern was similar for both minor and major operations. The length of intravenous therapy was longer before the new protocol than after (6 [2-23] vs $3[1-43]$ days; $P=0.02)$. The length of days in intravenous therapy diminished after the ACERTO protocol by 3 days (6[2-23] vs 3 [1-48]; $P=0.02)$. However, significant difference was only found in minor operations. (Figure 2)

\section{Length of hospital stay}

Postoperative stay diminished by 4 days in the second period of the study (6[1-43] versus 2[1-97] days; $P=0.002)$. In major operations however, there was no significant difference between the two periods $(10.5[3-43]$ vs $8[2-97] ; P=0.21)$ (Table 3). However, in the subset of major operations perprotocol analysis showed that postoperative stay was shortened by 2 days $(P<0.01)$ only in patients who completed the entire protocol (conventional $=10$ [3-43] days; non-completed ACERTO protocol $=9$ [2-97] days, and completed ACERTO protocol $=8[2-20]$ days) .

\section{Postoperative mortality and morbidity}

Mortality was $3.4 \%$ (four cases) with two cases in each period $(P=0.62)$. Surgical site infection rate significantly fell after the implementation of the ACERTO protocol (19.0\%; $8 / 42$ versus $2.7 \% ; 2 / 75 ; P<0.001$; relative risk $(\mathrm{RR})=1.20 ; 95 \%$ confidence interval $(\mathrm{CI})=1.03-1.39)$. This difference was due to a significant decrease of surgical site infections after major operations $(37.6 \% ; 6 / 42$ vs $5.7 \% ; 2 / 75 ; P=0.01 ; \mathrm{RR}=1.37$; $95 \% \mathrm{CI}=1.01-1.89$ ). Overall, morbidity rate had a tendency to diminish in the second period of the study $(38.1 \% ; 16 / 42$ vs $21.3 \% ; 16 / 75 ; P=0.05 ; \mathrm{RR}=1.27 ; 95 \% \mathrm{CI}=0.97-1.65)$. There was no difference in the number of anastomotic dehiscence, reoperations, and intra-abdominal abscesses between the two periods (data not showed). Per-protocol analysis showed that surgical infection rate diminished after the new protocol independently of patients who completed or not completed the entire protocol. However, overall morbidity decreased only when the ACERTO protocol was fulfilled (Table 3 ).

\section{DISCUSSION}

The findings showed that the implementation of the ACERTO protocol enhanced the recovery after operations in elderly patients. These benefits were shown in various postoperative parameters. Not only LOS and postoperative stay
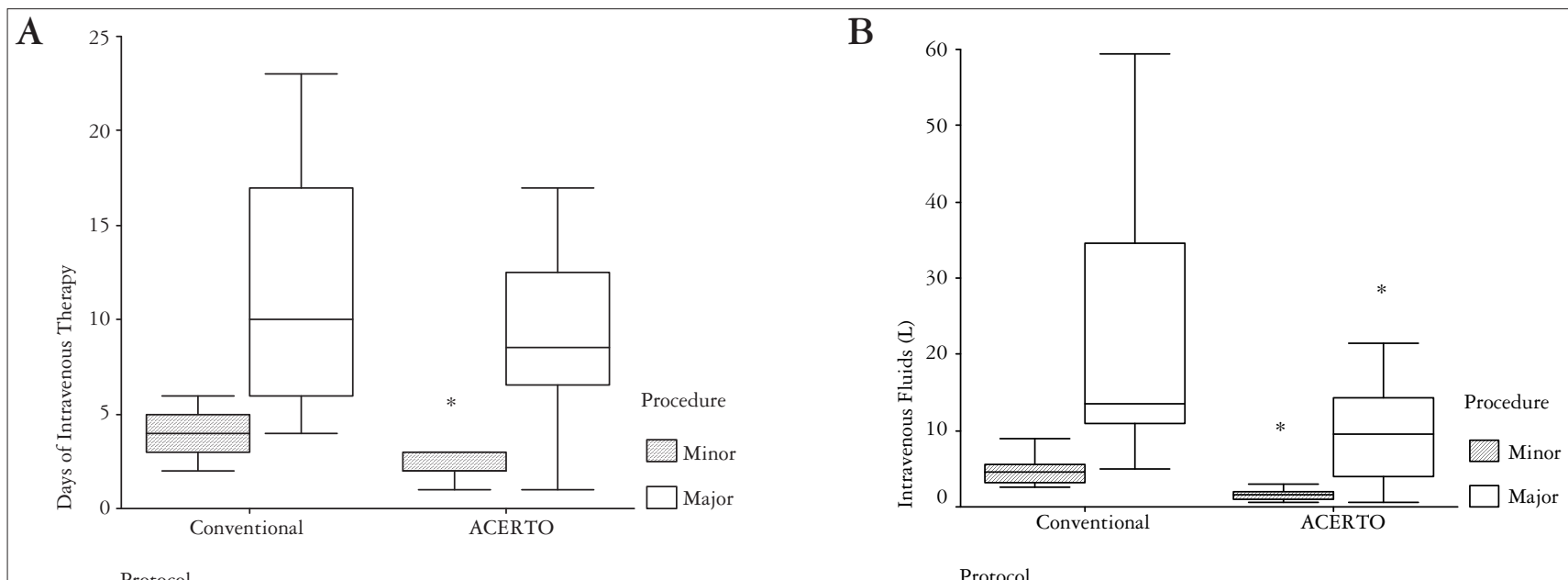

Protocol

Protocol

FIGURE 2. Days of postoperative intravenous therapy (A) and total volume of intravenous fluids (B) in the two protocols of the study. $*, P<0.01$ versus conventional group 
TABLE 3. Clinical outcome according to the phase and completion of the ACERTO protocol

\begin{tabular}{lccc}
\hline & \multicolumn{3}{c}{ ACERTO Protocol } \\
\cline { 2 - 4 } Outcome & $\begin{array}{c}\text { Before } \\
(\mathrm{n}=42)\end{array}$ & $\begin{array}{c}\text { Complete } \\
(\mathrm{n}=40)\end{array}$ & $\begin{array}{c}\text { Incomplete } \\
(\mathrm{n}=35)\end{array}$ \\
\hline Postoperative LOS * & $6(1-43)$ & $2(1-13)^{\dagger}$ & $7(1-97)$ \\
SSI $(\mathrm{n} ; \%)$ & $8(19)$ & $1(2.5)^{\dagger}$ & $1(2.8)^{\dagger}$ \\
Morbidity (n;\%) & $16(38.1)$ & $5(12.5)^{\dagger}$ & $11(31.4)$ \\
Anastomotic dehiscence (n ; \%) & $2(4.7)$ & $2(5.0)$ & $1(2.8)$ \\
Mortality (n; $\%)$ & $2(4.7)$ & $0(0)$ & $2(5.7)$ \\
\hline
\end{tabular}

LOS = length of stay; SSI = surgical site infection

*Median and range:

$=P<0.01$ vs before ACERTO

shortened but also both surgical site infection and morbidity rates diminished. Elderly subjects submitted major operations and completed the entire ACERTO protocol were the most benefited. These results are significant because surgical site infection in elderly patients is associated with approximately four times greater mortality ${ }^{(17)}$. Moreover the findings indirectly suggest that an important institutional endpoint as hospital costs was probably cut down.

Perioperative multimodal approaches have significantly impacted the outcome in general surgery ${ }^{(13,18)}$. Various traditional surgical routines such as routine use of nasogastric intubation and abdominal drains when examined by the sight of the evidence based medicine paradigm have failed to demonstrate their usefulness ${ }^{(12,22,25)}$. In opposition to traditional 6-8 hours of "nil by mouth" routine, the abbreviation of pre-operative fasting not only is safe but also decreases insulin resistance ${ }^{(20,}$ 23) and preserves skeletal muscle mass after surgery ${ }^{(32)}$. In addition the prescribed fasting time is usually enlarged by several reasons ${ }^{(2,4)}$. The findings in the present study showed that it may increase by 2 -fold. This delay may initiate a metabolic response to fasting that may enhance the catabolic response after the trauma. The implementation of the new protocol safely reduced preoperative fasting time by 3 -fold. Intake of carbohydrate beverage 2 hours before operation may diminish postoperative discomfort ${ }^{(17)}$ and episodes of nausea/vomiting ${ }^{(3,15)}$. Aged subjects are most fragile and thus more susceptible to complications due to variations of the homeostasis ${ }^{(17)}$.

Various randomized trails $\mathrm{s}^{(1,29)}$ and meta-analisys $\mathrm{s}^{(5,19)}$ concluded that early feeding after intestinal anastomosis is safe, reduces postoperative ileus, shortens LOS, and does not impair the healing of gastrointestinal anastomosis ${ }^{(19)}$. Our findings showed that aged subjects were safely fed 1 day earlier than before contributing to both rapid freeing of intravenous fluids and early hospital discharge.

Malnutrition is very prevalent among aged people and a continuing source of concern, particularly among hospitalized patients ${ }^{(27)}$. Our data are in accordance and have showed that malnutrition is highly prevalent in this subset of surgical patients. There were no modifications on perioperative nutritional support data before and after the new protocol. This finding was due to our previous concept in the former protocol that remained in the ACERTO protocol: undernourished patients should receive pre-operative nutritional support for 7-10 days ${ }^{(2,4)}$.
There are serious clinical implications of excessive perioperative fluid administration. In addition, a worst tolerance to intravenous fluids in either malnourished or elderly patients is well accepted ${ }^{(16)}$. Regimens of restrict use of fluids are associated with less postoperative complications and shorten postoperative stay ${ }^{(7)}$. Generous intravenous fluids therapy increases body weight and may cause edema, pulmonary complications, and prolonged ileus ${ }^{(7,16,21,30)}$. A significant fall of intravenous fluid prescription at postoperative period was achieved after the ACERTO protocol was initiated. In addition, the number of days of intravenous therapy was reduced by 3 days. The new protocol reduced by 4 -folds the total volume of fluids which represented a median reduction of approximately $8 \mathrm{~L}$ of fluids per patient. This modification has certainly implied in the overall postoperative results.

The ACERTO protocol abolished in our hospital the use of preoperative mechanical preparation of the colon for elective colorectal operations. This police was based on various meta-analysis that have consistently documented that there is no benefit in cleansing the large bowel preoperatively and furthermore, this traditional preoperative care may be harmful and increase the risk of colonic anastomotic dehiscence $^{(8,28)}$. A recent well-design multicentric randomized trail including 1400 patients conclude that mechanical bowel preparation before elective colorectal surgery can safely be abandoned ${ }^{(10)}$. Accordingly, the number of anastomotic dehiscence in this study was not increased after the adoption of the new protocol.

The difficulties of implementing a multimodal strategies like the ACERTO protocol were expected since the adherence to the new routines was let be in free-willing basis. Therefore only $53.3 \%$ of cases completed the entire protocol. These difficulties have been reported in a recent paper ${ }^{(26)}$. Possibly, a much longer period of experience is necessary to rupture with the longstanding traditions in conventional care. Nonetheless elderly subjects who completed the protocol have a significant improvement in the outcome.

The study has some limitations that need to be pointed out. The two groups were not randomized, they were unequal in size and conclusions were based upon comparisons between two periods. However the two groups were similar in many clinical characteristics such as the incidence of malnutrition, major procedures, malignancies, ASA score, and length of operative time. Thus, the best results may reflect the evolution of perioperative care between the two periods.

Our findings are in complete agreement with other authors and guidelines that advocate the changing of the traditional routines of perioperative care ${ }^{(13,24,32)}$. The overall results allow us to conclude that the adoption of the ACERTO protocol in elderly patients was followed by a significant fall of surgical site infection rate and faster recovery of the patients.

\section{CONCLUSIONS}

The implementation of multimodal strategies may provide clear benefits for aged patients submitted to abdominal operations, mainly on the digestive tract. 
Aguilar-Nascimento JE, Salomão AB, Caporossi C, Diniz BN. Benefícios clínicos após a implementação de um protocolo multimodal perioperatório em paciente idosos. Arq Gastroenterol. 2010;47(3);178-83.

RESUMO - Contexto - Protocolos multimodais de cuidados perioperatórios podem acelerar a recuperação pós-operatória. Fundamentadas na medicina baseada em evidência, essas novas rotinas mudam as prescrições convencionais em cirurgia. Objetivo - Avaliar os resultados de um protocolo multimodal (protocolo ACERTO) em pacientes idosos. Métodos - Estudo de coorte histórica não aleatório realizado na enfermaria de cirurgia de um hospital universitário terciário. Cento e dezessete pacientes com idade igual ou superior a 60 anos foram submetidos a operações abdominais eletivas sob um protocolo convencional $(n=42$; grupo convencional, janeiro 2004-junho 2005) ou um protocolo multimodal denominado ACERTO ( $\mathrm{n}=75$; grupo ACERTO, julho 2005-dezembro 2007). As principais variáveis de resultado foram: tempo de jejum pré-operatório, tempo de realimentação pósoperatória, volume de fluidos intravenosos, tempo de internação e morbidade. Resultados - A implantação do protocolo ACERTO foi acompanhada de queda do tempo de jejum pré-operatório $(15$ [8-20] vs 4 [2-20] horas, $P<0.001)$, do dia de realimentação pós-operatória $\left(1^{\circ}\left[1^{\circ}-10^{\circ}\right]\right.$ vs $0\left[0-5^{\circ}\right]$ dia de pós-operatório; $P<0,01)$ e do volume de fluídos intravenosos $(10,7[2,5-57,5]$ vs $2,5[0,5-82] \mathrm{L}, P<0,001)$. A mudança de protocolo reduziu o tempo médio de internação hospitalar em quatro dias (6[1-43] vs 2[1-97] dias; $P=0,002)$ e a taxa de infecção do sítio cirúrgico em 85,7\% (19\%; 8/42 vs $2,7 \% ; 2 / 75, P<0,001 ;$ risco relativo $=1,20 ; 95 \%$ intervalo de confiança $=1,03-1,39)$. Análise per-protocolo mostrou que a permanência hospitalar em operações de grande porte diminuiu apenas no subgrupo de pacientes nos quais o protocolo foi completo $(P<0,01)$. Conclusão - A implantação de rotinas multidisciplinares do protocolo ACERTO diminuiu a hospitalização e a infecção de sitio cirúrgico em pacientes idosos submetidos a operações abdominais.

Descritores - Assistência perioperatória. Cuidados pós-operatórios. Tempo de internação. Idoso. Protocolos.

\section{REFERENCES}

1. Aguilar-Nascimento JE, Goelzer J. Alimentação precoce após anastomoses intestinais: riscos ou benefícios? Rev Assoc Med Bras. 2002;48:348-52.

2. Aguilar-Nascimento JE, Salomão AB, Caporossi C, Silva RM, Cardoso EA, Santos TP. Acerto pós-operatório: avaliação dos resultados da implantação de um protocolo multidisciplinar de cuidados peri-operatórios em cirurgia geral [Acerto project: outcome evaluation after the implementation of a multidisciplinary protocol of peri-operative care in general surgery]. Rev Col Bras Cir. 2006;33:181-8.

3. Aguilar-Nascimento JE, Dock-Nascimento DB, Faria MSM, Maria EV, Yonamine F, Silva MR, Adler T. Ingestão pré-operatória de carboidratos diminui a ocorrência de sintomas gastrointestinais pós-operatórios em pacientes submetidos à colecistectomia [Preoperative ingestion of carbohydrates diminishes the occurrence of postoperative gastrointestinal symptoms in patients submitted to cholecystectomy]. ABCD Arq Bras Cir Dig. 2007;20:77-80.

4. Aguilar-Nascimento JE, Bicudo-Salomão A, Caporossi C, Silva RM, Cardoso EA, Santos TP. Enhancing surgical recovery in Central-West Brazil: the ACERTO protocol results. e-SPEN The European e-Journal of Clinical Nutrition and Metabolism. 2008;3:e78-e83.

5. Andersen HK, Lewis SJ, Thomas S. Early enteral nutrition within $24 \mathrm{~h}$ of colorectal surgery versus later commencement of feeding for postoperative complications. Cochrane Database Syst Rev. 2006;18:CD004080.

6. Bardram L, Funch-Jensen P, Kehlet H. Rapid rehabilitation in elderly patients after laparoscopic colonic resection. Br J Surg. 2000;87:1540-5.

7. Brandstrup B, Tonnesen H, Beier-Holgersen R,Hjortso E, Ording H, LindorffLarsen K, Rasmussen MS, Lanng C, Wallin L, Iversen LH, Gramkow CS, Okholm M, Blemmer T, Svendsen PE, Rottensten HH, Thage B, Riss J, Jeppesen IS, Teilum D, Christensen AM, Graungaard B, Pott F. Effects of intravenous fluid restriction on postoperative complications: comparison of two perioperative fluid regimens: a randomized assessor-blinded multicenter trial. Ann Surg. 2003;238:641-8.

8. Bucher P, Mermillod B, Gervaz P, Morel P. Mechanical bowel preparation for elective colorectal surgery: a meta-analysis. Arch Surg. 2004;139:1359-64

9. Camargos MC, Machado CJ, Rodrigues RN. Life expectancy among elderly Brazilians in 2003 according to different levels of functional disability. Cad Saude Publica. 2008;24:845-52.

10. Contant CM, Hop WC, van't Sant HP, Oostvogel HJ, Smeets HJ, Stassen LP, Neijenhuis PA, Idenburg FJ, Dijkhuis CM, Heres P, van Tets WF, Gerritsen JJ, Weidema WF. Mechanical bowel preparation for elective colorectal surgery: a multicentre randomised trial. Lancet. 2007;370:2112-7.

11. Detsky AS, McLaughlin JR, Baker JP, Johnston N, Whittaker S, Mendelson RA, Jeejeebhoy KN. What is subjective global assessment of nutritional status? JPEN J Parenter Enteral Nutr. 1987;11:8-13.
12. Fearon KC, Luff R. The nutritional management of surgical patients: enhanced recovery after surgery. Proc Nutr Soc. 2003;62:807-11.

13. Fearon KC, Ljungqvist $\mathrm{O}$, Von Meyenfeldt $\mathrm{M}$, Revhaug A, Dejong CH, Lassen K, Nygren J, Hausel J, Soop M, Andersen J, Kehlet H. Enhanced recovery after surgery: a consensus review of clinical care for patients undergoing colonic resection. Clin Nutr. 2005;24:466-77.

14. Hausel J, Nygren J, Lagerkranser M, Hellström PM, Hammarqvist F, Almström C, Lindh A, Thorell A, Ljungqvist $\mathrm{O}$. A carbohydrate-rich drink reduces preoperative discomfort in elective surgery patients. Anesth Analg. 2001;93:1344-50.

15. Hausel J, Nygren J, Thorell A, Lagerkranser M, Ljungqvist O. Randomized clinical trial of the effects of oral preoperative carbohydrates on postoperative nausea and vomiting after laparoscopic cholecystectomy. Br J Surg. 2005;92: 415-21.

16. Holte K, Sharrock NE, Kehlet H. Pathophysiology and clinical implications of perioperative fluid excess. Br J Anaesth. 2002;89:622-32.

17. Kaye KS, Anderson DJ, Sloane R, Chen LF, Choi Y, Link K, Sexton DJ, Schmader KE. The effect of surgical site infection on older operative patients. J Am Geriatr Soc. 2009;57:46-54.

18. Kehlet H, Wilmore DW. Multimodal strategies to improve surgical outcome. Am J Surg. 2002;183:630-41

19. Lewis SJ, Egger M, Sylvester PA, Thomas S. Early enteral feeding versus "nil by mouth" after gastrointestinal surgery: systematic review and meta-analysis of controlled trials. BMJ. 2001;323:773-6.

20. Ljungqvist O, Soreide E. Preoperative fasting. Br J Surg. 2003;90:400-6.

21. Lobo DN, Bostock KA, Neal KR, Perkins AC, Rowlands BJ, Allison SP. Effect of salt and water balance on recovery of gastrointestinal function after elective colonic resection: a randomised controlled trial. Lancet. 2002;359:1812-8.

22. Nelson R, Tse B, Edwards S. Systematic review of prophylactic nasogastric decompression after abdominal operations. Br J Surg. 2005;92:673-80.

23. Nygren J, Thorell A, Ljungqvist O. Preoperative oral carbohydrate nutrition: an update. Curr Opin Clin Nutr Metab Care. 2001;4:255-9.

24. Nygren J, Hausel J, Kehlet, H, Revhaug A, Lassen K, Dejong C, Andersen J, von Meyenfeldt M, Ljungqvist O, Fearon KC. A comparison in five European Centers of case mix, clinical management and outcomes following either conventional or fast-track perioperative care in colorectal surgery. Clin Nutr. 2005;24:455-61.

25. Petrowsky H, Demartines N, Rousson V, Clavien PA. Evidence-based value of prophylactic drainage in gastrointestinal surgery: a systematic review and metaanalyses. Ann Surg. 2004;240:1074-84.

26. Polle SW, Wind J, Fuhring JW, Hofland J, Gouma DJ, Bemelman WA. Implementation of a fast-track perioperative care program: what are the difficulties? Dig Surg. 2007;24:441-9.

27. Poulsen I, Rahm Hallberg I, Schroll M. Nutritional status and associated factors on geriatric admission. J Nutr Health Aging. 2006;10:84-90. 
28. Slim K, Vicaut E, Panis Y, Chipponi J. Meta-analysis of randomized clinical trials of colorectal surgery with or without mechanical bowel preparation. $\mathrm{Br} \mathrm{J}$ Surg. 2004;91:1125-30.

29. Stewart BT, Woods RJ, Collopy BT, Fink RJ, Mackay JR, Keck JO. Early feeding after elective open colorectal resections: a prospective randomized trial. Aust N Z J Surg. 1998;68:125-8.

30. Tambyraja AL, Sengupta F, MacGregor AB, Bartolo DC, Fearon KC. Patterns and clinical outcomes associated with routine intravenous sodium and fluid administration after colorectal resection. World J Surg. 2004;28:1046-51

31. Waitzberg DL, Caiaffa WT, Correia MI. Hospital malnutrition: the Brazilian national survey (IBRANUTRI): a study of 4000 patients. Nutrition. 2001;17:573-80.
32. Weimann A, Braga M, Harsanyi L, Laviano A, Ljungqvist O, Soeters P. ESPEN Guidelines on Enteral Nutrition: Surgery including organ transplantation. Clin Nutr. 2006;25:224-44.

33. Yuill KA, Richardson RA, Davidson HI, Garden OJ, Parks RW The administration of an oral carbohydrate-containing fluid prior to major elective upper-gastrointestinal surgery preserves skeletal muscle mass postoperatively-a randomised clinical trial Clin Nutr. 2005;24:32-7.

Received 14/10/2009. Accepted 21/1/2010 